IFN Working Paper No. 1096, 2015

\title{
The Impact of Board Internationalization on Earnings Management
}

Reggy Hooghiemstra, Niels Hermes, Lars Oxelheim and Trond Randøy 


\title{
The Impact of Board Internationalization on Earnings Management
}

\author{
Reggy Hooghiemstra \\ Faculty of Economics and Business, Department of Accounting and Auditing, \\ University of Groningen
}

Niels Hermes

Faculty of Economics and Business, Department of Economics, Econometrics and Finance, University of Groningen

Lars Oxelheim

Research Institute of Industrial Economics, Stockholm; and School of Law and Business, University of Agder, Kristiansand

Trond Randøy

School of Law and Business, University of Agder, Kristiansand

\begin{abstract}
Prior literature shows that choices regarding board composition are associated with earnings management. We add to this literature by examining the effects of the presence of a foreign board member on earnings management. Using a sample of 3,249 firm-year observations representing 586 non-financial listed Nordic firms during 2001-2008, we find that the presence of a non-Nordic, foreign director is associated with significantly higher levels of earnings management. Moreover, we provide preliminary evidence that differences in accounting knowledge drive this effect. Our results suggest that it may not necessarily be beneficial to appoint a foreign director to the board.
\end{abstract}

Keywords: Earnings management; Board composition; Internationalization; Foreign board member; Accounting knowledge

JEL Classification: G34; M16; M41; M52

Lars Oxelheim acknowledges financial support from NASDAQOMX Nordic Foundation. 


\section{Introduction}

One of the main responsibilities of the board of directors is to ensure the quality of the firm's financial statements. This is a legal requirement in most countries and is highlighted as one of the fundamental principles of good corporate governance (OECD, 2004). It is generally accepted that the quality of the firm's financial statements is compromised when corporate decision makers implement earnings management opportunistically. Earnings management refers to choices made by corporate decision makers using accounting methods offered by law and regulations to influence a firm's reported earnings (Chen, Luo, Tang \& Tong, 2014).

Prior research has documented the importance of the board of directors in the financial reporting process in general and in mitigating earnings management in particular (Dechow, Ge \& Schrand, 2010; Larcker, Richardson \& Tuna, 2007). Specifically, a growing literature shows that board characteristics, such as board independence (Bruyneels \& Cardinaels, 2014; Hwang \& Kim, 2009), the presence of an audit committee (García-Meca \& Sánchez-Ballesta, 2009; Klein, 2002), and female representation on the board (Adams \& Ferreira, 2009; Srinidhi, Gul \& Tsu, 2011) are associated with reduced levels of earnings management.

Our study contributes to this literature by adding an international dimension, i.e. the presence of a foreign board member on the firm's board. In particular, we claim that having one or more foreign board members may potentially reduce a board's ability to ensure the quality of the financial statements. To support this claim, we argue that foreign board members are more likely to suffer from a lack of knowledge of local (accounting) rules and/or that their presence makes the board vulnerable to language issues, which hampers board effectiveness and, hence, increases earnings management. As such, our research is part of an emerging field that focuses on the antecedents and consequences of the internationalization of the board of directors (Attig, Boubakri, El Ghoul \& Guedhami, 2014; Masulis, Wang \& Xie, 2012; Oxelheim \& Randøy, 2005; Oxelheim, Gregorič, Randøy \& Thomsen, 2013; Piekkari, Oxelheim \& Randøy, 2015).

We investigate the association between the presence of foreign directors and earnings management using a sample of 3,249 firm-year observations representing 586 non-financial listed Nordic firms during 2001-2008. We find the Nordic region (i.e., Denmark, Finland, Norway, and 
Sweden) to be particularly useful as a context for our research, as the number of firms with an internationalized board is relatively high in Nordic firms (Oxelheim et al., 2013). Moreover, the number of Nordic firms with an internationalized board has increased substantially in the past decade.

As earnings management involves an inherently unobservable process (Nam, Park \& Arthurs, 2014), we use discretionary accruals to detect the level of earnings management (Klein, 2002; Srinidhi et al., 2011). After controlling for several variables associated with earnings management, we find that the presence of a non-Nordic, foreign director is associated with significantly higher levels of earnings management, favoring the notion that these foreign directors are less effective monitors. We obtain largely similar findings from OLS, an instrumental variables approach and propensity score matching. We further explore reasons why foreign board members are less effective monitors and find some supportive evidence for the notion that they lack the specific knowledge of national accounting rules and laws. Our results favor the interpretation that appointing a foreign director to the board of directors can reduce the board's ability to discipline managers as far as earnings management is concerned.

The remainder of the paper is organized as follows. Section two reviews the relevant literature and states the hypothesis. The third section presents the research design, and the fourth section provides the empirical analyses and results. The last section gives the concluding remarks.

\section{Literature review and hypothesis development}

A key premise of agency theory is that firms characterized by a separation of ownership and control are fraught with agency problems between managers and shareholders (Fama \& Jensen, 1983; Jensen \& Meckling, 1976). Information asymmetry between managers and shareholders provides selfinterested managers with the opportunity to behave opportunistically and to increase their personal wealth at the expense of the shareholders. One manifestation of agency problems is lower earnings quality as indicated, for instance, by higher levels of earnings management. Healy and Wahlen (1999: 368) define earnings management as behavior in which corporate decision makers use judgment in financial accounting to alter financial reports in an attempt to either mislead the shareholders about the firm's performance or to influence contractual outcomes that depend on reported accounting numbers. 
Following agency theory, the board of directors is a crucial mechanism to constrain managers' opportunistic behavior. In particular, prior accounting literature shows that the choice regarding board composition comprises an important governance mechanism to mitigate earnings management (Ahmed \& Duellman, 2007; Dechow et al., 2010). Specifically, research shows that to curb earnings management a board should mainly comprise independent directors (Bruyneels \& Cardinaels, 2014; Hwang \& Kim, 2009; Klein, 2002), should have at least one female director (Adams \& Ferreira, 2009; Srinidhi et al., 2011), and should have installed an audit committee (García-Meca \& Sánchez-Ballesta, 2009; Klein, 2002). In this study, we focus on how the internationalization of a corporate board-i.e., hiring a foreign board member—can affect the board's ability to ensure the quality of financial statements.

There are two competing views in the literature that may explain the possible impact of foreign directors on earnings management. One view is that the presence of foreign directors increases the effectiveness of the board of directors and, thus helps to curb earnings management. As foreign directors usually do not come from the same pool of directors (Ruigrok et al., 2007), i.e., come from outside the "old boys network," it is likely that boards that include at least one foreign director are associated with a growing tendency of directors to emphasize openness and frankness in performing their monitoring tasks, rather than giving priority to politeness and courtesy among board members (Chiu, Teoh \& Tian, 2010; Oxelheim \& Randøy, 2003). At the same time, the presence of foreign directors may help prevent too high levels of cohesiveness ${ }^{\mathrm{i}}$ of the board (Forbes \& Milliken, 1999). That is, as these directors come from outside the (local or national) inner circle of directors, they are more likely to exhibit independent thinking and to feel less reluctant to raise controversial issues. This may benefit discussions within the boardroom and potentially contribute to increased monitoring effectiveness (Srinidhi et al., 2011). Moreover, foreign directors may bring different viewpoints to the boardroom given their different backgrounds and experiences. Again, this may raise the effectiveness of boards when it comes to carrying out their monitoring task.

The combination of these effects is likely to foster an environment in which tougher questions are asked. This view, which emphasizes that the presence of a foreign director contributes to a board that is more likely to critically scrutinize the manager, suggests that the presence of a foreign director is 
associated with reduced levels of earnings management. Accordingly, this line of reasoning suggests the following hypothesis:

Hypothesis 1. There is a negative association between the presence of a foreign director in the board of directors and the level of earnings management.

A competing view emphasizes that foreign directors may be less well-equipped to perform their monitoring tasks. Foreign directors can be less effective monitors for reasons related to lack of knowledge of accounting rules as well as due to language issues.

First, a foreign director may be less familiar with local laws, regulations and governance standards in general and local accounting rules in particular (Masulis et al., 2012). This (relative) unfamiliarity with local accounting rules may impair the foreign director's ability to effectively evaluate the level of opportunism in the manager's judgment in financial accounting. Specifically, prior literature suggests that domain-specific knowledge of accounting is important for a director to monitor the manager’s financial reporting practices and to mitigate the manager's tendencies to engage in earnings management. According to Dhaliwal, Naiker \& Navissi (2010: 792), financial reporting issues involve high levels of technical details and, hence, a high degree of knowledge of accounting rules are required to recognize critical accounting issues at such high levels of earnings management. Indeed, in line with this conjecture, evidence demonstrates that boards including at least one individual with financial (accounting) expertise are associated with higher financial reporting quality (Dhaliwal et al., 2010; Krishnan \& Visvanathan, 2008; Zhang, Zhou \& Zhou, 2007). While since 2005 national and international generally accepted accounting standards have converged in Europe as a consequence of the requirement that publicly listed companies have to prepare financial statements in accordance with the International Financial Reporting Standards (IFRS), ${ }^{\text {ii }}$ this was not the case in the pre-IFRS period. Hence, at least in the pre-IFRS period, a high degree of local (i.e., national) accounting knowledge was required to effectively monitor the financial reporting process; knowledge that foreign directors are not likely to possess.

A second potential obstacle a foreign director faces is language (Kassis-Henderson, 2005, 2010; Piekkari et al., 2015; Tenzer, Pudelko \& Harzing, 2014). Although English seems to be the lingua franca of boards that include a foreign director (Piekkari et al., 2015), language potentially affects the 
effectiveness of the board in two ways. To begin with, at the individual level language may impair the director’s ability to effectively contribute to discussions in the boardroom (Piekkari et al., 2015). Specifically, a director's proficiency in English is likely to affect her cognitive processing and communication abilities (Kassis-Henderson, 2010). Not feeling comfortable in using English may for instance increase a director's insecurity and feelings of anxiety (Tenzer et al., 2014), which may negatively affect the extent to which an individual director contributes to discussions in the boardroom (Piekkari et al., 2015).

Moreover, at the board level research suggests that language affects interpersonal trust relations and the working atmosphere in teams (Kassis-Henderson, 2005; Tenzer et al., 2014). These aspects are crucial for any group, but particularly for groups that meet sporadically (Forbes \& Milliken, 1999), as these aspects contribute to an environment that stimulates discussion and collaboration. For instance, native and non-native speakers differ in terms of the ability to hear messages "between the lines” as well as in terms of the level of formality they consider appropriate when addressing each other (Kassis-Henderson, 2010). Indeed, Forbes and Milliken (1999: 499) note that as board members meet only episodically, "they are unlikely to have time to fully resolve the attitudinal and linguistic differences that divide them”. Hence, as a consequence of linguistic differences in general and differences in proficiency in English in particular, boards are vulnerable to "interaction difficulties that prevent groups from achieving their full potential” (Forbes \& Milliken, 1999: 492).

The above discussion stresses that foreign directors are associated with lax monitoring of managers due to lack of knowledge and language issues. Accordingly, this line of reasoning suggests the following hypothesis:

Hypothesis 2. There is a positive association between the presence of a foreign director in the board of directors and the level of earnings management.

\section{Research design}

\subsection{Data source and sample}

Our sample is based on the population of all publicly traded non-financial firms headquartered in Denmark, Finland, Norway or Sweden. These four Nordic countries have a number of legal and 
linguistic aspects in common. The Nordic countries comprise a relatively homogeneous region in terms of financial reporting regulation and practices (Aisbitt, 2001, 2002; Caban-Garcia \& He, 2013). Regarding the linguistic aspects, Piekkari et al. (2015) note that the Nordic region represents a region with a high degree of proficiency in English, while at the same time three of the four languages (i.e., Danish, Norwegian and Swedish) resemble each other as they are Scandinavian languages and belong to family of Germanic idioms.

Our initial sample includes all listed, non-financial firms headquartered in a Nordic country at the end of 2006. For these firms, we manually collect data for that year on relevant board variables, such as the identities of the CEO and directors, their nationality, gender, and date of first appointment of the chairman to the board. On the basis of this first round, the data collection was then extended to include each of the years 2001-2008. ${ }^{\text {iii }}$ Complete information with respect to the aforementioned director aspects were available for a total of 3,428 firm-year observations relating to 617 unique firms.

Next, for our empirical analysis, the hand-collected director data was merged with financial data from Compustat Global; and the information on market capitalization came from Datastream. This reduced the unbalanced sample to 3,249 firm-year observations (comprising 668 firm-year observations for Denmark, 685 for Finland, 480 for Norway and 1,416 for Sweden) representing 586 unique firms, for which we have all necessary data.

\subsection{Variables}

\section{Dependent variable}

Consistent with numerous accounting and finance studies, we employ the absolute value of the discretionary (or abnormal) accruals as a proxy for earnings management (Ghosh \& Olsen, 2009; Katz, 2009; Klein, 2002; Larcker et al., 2007; Peasnell, Pope \& Young, 2005; Peek, Meuwissen, Moers, Vanstraelen, 2013; Xie, Davidson III \& DaDalt, 2003). Specifically, and similar to recent studies, we focus on working capital accruals, as they are relatively easy to manage, but are less easy to detect by investors (Peek et al., 2013; Xie et al., 2003). We identify the "non-discretionary" accruals using the Modified Jones model (Dechow, Sloan \& Sweeney, 1995). In the Modified Jones 
model, the discretionary accruals proxy is the residual from a linear regression of working capital accruals on change in sales (after subtracting the change in accounts receivables) or:

$$
\frac{\mathrm{WCA}_{i t}}{\mathrm{AT}_{i t-1}}=\beta_{0}+\beta_{1}\left(\frac{\Delta \mathrm{REV}_{i t}-\Delta \mathrm{AR}_{i t}}{\mathrm{AT}_{i t-1}}\right)+\varepsilon_{i t}
$$

where $\mathrm{WCA}_{i t}$ denotes the working capital accruals of firm $i$ in year $t,{ }^{\mathrm{iv}} \mathrm{AT}_{i t-1}$ the total assets of firm $i$ in year $t-1, \Delta \mathrm{REV}_{i t}$ the change in revenues of firm $i$ in year $t$, and $\Delta \mathrm{AR}_{i t}$ the change in accounts receivable of firm $i$ in year $t$. The absolute value of $\varepsilon_{\mathrm{it}}$ in equation (1) is our dependent variable (MJ_ABSOLUTE).

As Peek et al. (2013) observe, in most U.K. and U.S. based studies the models used to estimate discretionary accruals are estimated by industry and year. However, this approach, they remark, is not feasible in many cross-country studies given the small sample sizes of the several countries. This we estimate the Modified Jones model by country, industry, and time period, where we distinguish two time periods: 2001-2004 and 2005-2008, with the last period coinciding with the first four years after the adoption of IFRS. The industry classification is based on one-digit SIC codes.

\section{Explanatory variables}

Our explanatory variables intend to measure the impact of the presence of at least one foreign director (D_FOREIGN) on the firm's board of directors on the level of earnings management. However, the four Nordic countries in our sample comprise a rather homogeneous region and there seems to be a Nordic labor market for directors (rather than separate markets for Danish, Finnish, Norwegian, and Swedish directors. Board interlocks are a well-known phenomenon in the Nordic countries where the pool of qualified candidates is limited (Oxelheim \& Randøy, 2003; Piekkari et al., 2015). For instance, Piekkari et al. (2015) indicate that the Nordic countries have a "corporate environment that can be characterized as a "small world" in that trust, information and reputation of individual board members spread quickly and shape board behavior (Sinani, et al., 2008).” Therefore, next to focusing on foreign board members in general, we also construct an indicator variable (D_NONNORDIC), which assumes the value of one if at least one non-Nordic foreigner sits on the board of directors and zero otherwise. 


\section{Control variables}

Although the presence of foreign directors might affect board monitoring and decision making, other variables also influence board oversight and, hence, the level of earnings management. Therefore, and consistent with prior research, we control for a number of governance- and firm-specific variables that affect the level of earnings management.

Governance-specific control variables: First, we include BOARD_SIZE measured as the logarithm of the number of directors and serves as a measure of board effectiveness (Cheng, 2008; Chiu et al., 2013; Peasnell et al., 2005). Second, we include AUDITCOM, an indicator variable that assumes the value of one if the firm has an audit committee, and zero otherwise. Prior research demonstrates that the presence of a separate sub-committee within the board focusing on financial reporting issues is an important mechanism to curb earnings management (Dechow et al., 2010; Klein, 2002; Xie et al., 2003). ${ }^{\vee}$ Third, we include CEO_BOARD, an indicator variable that assumes the value of one if the CEO sits on the board. As indicated by Oxelheim et al. (2013) the Nordic countries have a so-called "semi-two-tier" system, which allows (but does not require) one executive (the CEO) to sit on the board of directors. Arguably, and similar to CEO duality in the United Kingdom and United States (Bruyneels \& Cardinaels, 2014; Dhaliwal et al., 2010; Peasnell et al., 2005; Srinidhi et al., 2011; Xie et al., 2003), allowing the CEO to sit on the board of directors could impair the ability of the board to exercise oversight (Adams, Hermalin \& Weisbach, 2010).

Fourth, we also include TENURE_CHAIR, measured as the logarithm of the number of years the incumbent chairman served as chairman. It can be expected that a more experienced chairman is associated with more effective oversight (Chan, Liu \& Sun, 2013; Dhaliwal et al., 2010). Lastly, as recent research shows that the presence of one or more female directors is associated with tougher monitoring in general and reduced levels of earnings management in particular (Adams \& Ferreira, 2009; Srinidhi et al., 2011), we also control for female representation on the firm's board of directors. Specifically, we include D_FEMALE, an indicator variable that takes on the value of one if the board of directors includes at least one female, and zero otherwise.

Firm-specific control variables: Apart from the board characteristics, we include a number of firm characteristics, including FIRM_SIZE (measured by the logarithm of the firms' total assets in 
constant year-2000 prices in million euros), $D \_L O S S$ (an indicator variable that assumes the value of one if the firm experienced a loss in a certain year and zero otherwise), $R O A$ (return on assets, defined as EBIT divided by total assets), and Market-to-Book (MTB), defined as the ratio of the market value of the firm to the book value of total assets. Prior studies (Bruyneels \& Cardinaels, 2014; Chan et al., 2013; Chiu et al., 2013; Dhaliwal et al., 2010; Ghosh \& Olsen, 2009; Larcker et al., 2007; Peasnell et al., 2005; Srinidhi et al., 2011; Xie et al., 2003; Zao \& Chen, 2008) show that these firm characteristics are associated with earnings management. Prior research shows that financial analysts comprise an important external governance mechanism and that firms followed by more analysts have less discretion to manage their earnings (Chen et al., 2014). Therefore, we include a variable, ANALYSTCOV, measured as the logarithm of one plus the number of financial analysts following the firm (as reported in the I/B/E/S database). Finally, D_ANGLOLIST is an indicator variable that takes on the value of one if the firm's shares are cross-listed in the U.S., and zero otherwise. Prior research shows that the financial reporting quality is higher for firms whose shares are cross-listed in the U.S. (Lang, Raedy \&Yetman, 2003; Shi, Magnan \& Kim, 2012), possibly due to a tougher corporate governance and financial reporting regime.

We also include an indicator variable, PERIOD, which assumes the value of one for post-IFRS years (2005-2008), and zero otherwise. Lastly, we include industry and country dummies.

\section{Results}

\subsection{Descriptive statistics}

Table 1, Panel A provides the summary statistics and Pearson correlations for the full sample. Regarding the test variable we observe that 20 percent of the boards have at least one non-Nordic board member.

\section{[Insert table 1 around here]}

Table 1, Panel A also shows that the average board of our sample firms has almost 7 members, with values ranging from 2 to 13. In 28 percent of the firm-year observations a separate audit committee was active. In our sample, the CEO sits on the board in about 42 percent of the firms. The average chairperson has 7.64 years of experience, which suggest a considerable amount of experience. 
59 percent of the sampled boards of directors have at least one female board member; a figure that is considerably higher than found in U.S.-based research (Adams \& Ferreira, 2009). A firm is followed on average by 7 financial analysts. Only 3 percent of the firms are cross-listed in the U.S.

Table 1, Panel A further shows that an average firm in our final sample has a return on assets $(R O A)$ of 3 percent, and in 28 percent of the firm-year observations the firm experienced a loss. The average size (in terms of the book value of assets) of the firms in our sample is $€ 1.15$ billion (in constant year-2000 prices).

Finally, table 1, provides the correlations for our main variables. The correlation patterns seen in Table 1, Panel A indicate no severe multicollinearity issues, except for a small number of cases. Specifically, we find high correlations among the test variables (which will be included separately in the regression analyses) as well as between FIRM_SIZE and BOARD_SIZE ( $\rho=0.59)$, FIRM_SIZE and ANALYSTCOV $(\rho=0.75)$, and ROA and $D \_L O S S(\rho=-0.55)$. The variance inflation factors (not reported), however, indicate no multicollinearity problems. To minimize the impact of extreme values, we winsorize each of the continuous variables used in the regressions at the top and bottom 1 percent.

Table 1, Panel B provides information on the cross-country differences in terms of board internationalization. The differences appear to be rather substantial. Whereas 15 per cent of all Danish firms have boards with at least one non-Nordic board member, this is 31.5 per cent for Norwegian firms. Table 1, Panel C shows that the percentage of boards having at least one non-Nordic board member has increased substantially over time, from 17 percent in 2001 to 24 percent in 2008.

\subsection{Main hypotheses testing}

Table 2 presents the main results with absolute abnormal accruals based on Modified Jones as the dependent variable. To test our empirical predictions, we use OLS regression with standard errors clustered by firm.

We start our empirical analysis showing that the presence of foreign directors per se-i.e. also including, for instance, cases where a Swedish individual is the only foreign director on the board of a firm headquartered in Norway—is not statistically significantly associated with earnings management. Specifically, column (1) of Table 2 shows that the effects of D_FOREIGN on absolute abnormal 
accruals are statistically not significant $(\beta=0.01 ; n . s$.$) . A plausible explanation for this insignificant$ effect may be that the four countries comprise a relatively homogeneous region in terms of financial reporting regulations and practices (Aisbitt, 2001, 2002; Caban-Garcia \& He, 2013). Moreover, three languages (Danish, Norwegian and Swedish) resemble each other (Piekkari et al., 2015). Hence, the mere presence of a foreign director on boards of Nordic firms does not necessarily result in dynamics caused by a more internationalized board as it also involves foreign individuals who resemble "local" directors. Because of this, differences in familiarity with local accounting rules and/or difficulties in communication due to language may not pose a major barrier to those Nordic boards where the only foreigner(s) is (are) from another Nordic country in performing their monitoring tasks.

Next we turn our attention to the effects of foreign directors who come from outside the Nordic region. As Table 2, column (2) shows, the effects of $D_{-}$NONNORDIC on absolute abnormal accruals are statistically significant and positive $(\beta=0.02 ; p$-value $<0.05)$. The results indicate that boards of directors that include at least one non-Nordic foreigner are associated with higher levels of earnings management and thus are in line with our hypothesis 2, i.e. there is a positive association between the presence of a foreign director in the board of directors and the level of earnings management due to a lack of knowledge and/or due to language issues. ${ }^{\text {vi }}$ The coefficients regarding the control variables are generally in line with prior research, even though some variables (e.g., FIRM_SIZE, ANALYSTCOV and D_ANGLOLIST) are not statistically significant.

\section{[Insert table 2 around here]}

\subsection{Alternative measures for board internationalization and discretionary accruals}

To check the robustness of the previous findings we first construct an indicator variable for the presence of at least two non-Nordic directors on the board (i.e., if $D \_N O N N O R D I C 2=1$, the board has two or more non-Nordic foreigners on the board of directors; and zero otherwise); i.e., a possible nonlinear relationship between foreign directors and earnings management may be present (Srinidhi et al., 2011). The results in Table 3, column (1) indicate that boards having at least two non-Nordic board members are associated with higher levels of earnings management $(\beta=0.02 ; p$-value $<0.05)$. ${ }^{\text {vii }}$

\section{[Insert table 3 around here]}


To further verify the robustness of our results, we construct a second variable,

PERC_NONNORDIC, representing the percentage of non-Nordic directors in the board. The positive association between the presence of a foreign directors and the level of earnings management due to a lack of knowledge and/or due to language issues may be affected when the proportion of foreign boards increases. The results in column (2) of Table 3 confirm the idea that a higher percentage of non-Nordic directors in the board is associated with more earnings management $(\beta=0.07 ; p$-value $<$ $0.05)$.

Taken together these robustness checks using alternative proxies for board internationalization affirm that the presence of non-Nordic foreigners on the firm's board is associated with higher levels of earnings management. ${ }^{\text {viii }}$

Finally, to check the robustness of the previous findings, we use an alternative measure for discretionary accruals. Though widely used in the earnings management literature, the modified Jones model is far from perfect in detecting earnings management (Dechow et al., 2010; Katz, 2009).

Therefore, and as recommended by Peek et al. (2013), we also use the Dechow and Dichev (2002) cash flow model which regresses working capital accruals on current cash flow, previous year's cash flow, and next year's cash flow. Hence, abnormal accruals are set equal to the residuals of the following regression equation:

$$
\frac{\mathrm{WCA}_{i t}}{\mathrm{AT}_{i t-1}}=\beta_{0}+\beta_{1}\left(\frac{\mathrm{CF}_{i t-1}}{\mathrm{AT}_{i t-2}}\right)+\beta_{1}\left(\frac{\mathrm{CF}_{i t}}{\mathrm{AT}_{i t-1}}\right)+\beta_{1}\left(\frac{\mathrm{CF}_{i t+1}}{\mathrm{AT}_{i t}}\right)+\varepsilon_{i t}
$$

where $\mathrm{CF}_{i t+\tau}$ is the cash flow from operations (i.e., current operating income minus accruals) of firm $i$ in year $t+\tau(\tau=-1,0,1)$, and the other variables are as defined previously. Similar to our main analyses, we estimate the models by country, industry, and time period, where we distinguish two time periods: 2001-2004 and 2005-2008. Untabulated results reaffirm the findings regarding our test variable based on the analyses using the Modified Jones model.

\subsection{Signed accruals}


So far, we have looked at the absolute value of discretionary accruals and, hence, treated incomeincreasing (i.e., upward) and income-decreasing (i.e., downward) earnings management similarly. However, to create a positive impression on the firm’s stakeholders (e.g., by showing improved financial performance), corporate decision-makers may be particularly likely to resort to incomeincreasing earnings management (Chen et al., 2014). At the same time, income-increasing earnings management may not be in the best interests of (future) investors (Graham, Harvey \& Rajgopal, 2005), when they base their investment decisions on reported results that are substantially higher than the firm's underlying fundamentals (Davidson, Jiraporn \& Nemec, 2004). Therefore, we conduct an analysis focusing on the signed accruals. The results are reported in Table 4.

\section{[Insert table 4 around here]}

Table 4 contains three columns. Column (1) shows the results based on the full sample. They indicate that the presence of a non-Nordic, foreign director is positively associated with the level of discretionary accruals $(\beta=0.018$; $p$-value $<0.01)$. Columns (2) and (3) provide sub-sample results for income-increasing and income-decreasing earnings management, respectively. The results in columns (2) and (3) indicate that the presence of a non-Nordic, foreign director is positively associated with the level of income-increasing earnings management $(\beta=0.037$; $p$-value $<0.05)$, but not with incomedecreasing earnings management $(\beta=0.009 ;$ n.s. $)$. These results seem to suggest that corporate decision makers use the board's reduced ability to detect or mitigate earnings management resulting from the presence of one or more foreign board members by engaging in income-increasing earnings management, but not by engaging in income-decreasing earnings management.

\subsection{Endogeneity of foreign directors on Nordic boards}

\section{Instrumental variables approach}

A common problem governance researchers face is endogeneity (Adams et al., 2010; Hermalin \& Weisbach, 2003). In our study, it is possible that foreign directors do not randomly join Nordic firms but, rather, self-select firms. To overcome this possible endogeneity bias, we follow prior research and use an instrumental variable (IV) approach where we estimate earnings management regressions in a two-stage least square (2SLS) framework (Larcker \& Rusticus, 2010; Lennox, Francis \& Wang, 2012). Consistent with Masulis et al. (2012) we use distance of headquarters to airport 
(DISTANCE_TO_AIRPORT) as our first instrument. DISTANCE_TO_AIRPORT captures "the intuition that foreign directors may prefer to sit on boards of firms whose headquarters they can more easily reach” (Masulis et al., 2012: 546). DISTANCE_TO_AIRPORT is an indicator variable that equals one if a firm's headquarter is located within $50 \mathrm{~km}$ of the country's international airport, and zero otherwise. Our second instrument is the percentage of foreign sales to total sales (PERC_FOREIGN_SALES). Arguably, the internationalization of the firm (for instance in terms PERC_FOREIGN_SALES) may explain board internationalization (i.e., explain why firms "demand" foreigners). Specifically, Oxelheim et al. (2013: 176) note that to deal with increased complexity due to the firm's internationalization foreign directors can help to provide a firm's board with the necessary advice, monitoring abilities and resources to meet the challenges of internationalization.

In the first stage, we estimate a probit model where the dependent variable is an (indicator) variable indicating whether a non-Nordic director sits on the firm's board and report the results in Panel A of Table 5. As expected, we find that our IVs (DISTANCE_TO_AIRPORT and PERC_FOREIGN_SALES) are significantly and positively related to our test variable.

\section{[Insert table 5 around here]}

In Panel B of Table 4, we estimate the second-stage regressions where the dependent variable is the absolute discretionary accrual and our indicator variable (i.e., D_NONNORDIC) is replaced by its instrumented value from the first stage. The model specifications are otherwise identical to those reported in our prior analyses. Results presented in Panel B of Table 5 show that the presence of a non-Nordic director still has a positive significant effect on the absolute value of discretionary accruals. The results affirm the evidence from the OLS regressions in prior analyses. The Hausmantest (significant at the 1\% level) suggests that it is important to control for endogeneity in our analyses. The Hansen-Sargan J-statistic is not significant suggesting that the exclusion restriction is met so that we can conclude that the two IVs are empirically valid. Lastly, the partial F-statistic (16.024) is greater than 10 , suggesting we have strong instruments.

\section{Propensity score matching}

Apart from the IV-approach, we used propensity score matching (PSM). The idea of propensity matching is to correct the estimation of the treatment effect (i.e., the presence of a non-Nordic 
director) for omitted variable bias by constructing matched pairs that are as similar as possible on the basis of observable characteristics (i.e., covariates). Such a full-dimensional matching approach can relax assumptions in OLS regression estimations and is therefore more robust (Armstrong, Guay \& Weber, 2010; Armstrong, Jagolinzer \& Larcker, 2010).

To implement this approach we first compile a sub-sample comprising all firms with at least one non-Nordic board member (i.e., "treatment firms”). We then derive propensity scores based on all explanatory variables that were also used in the regression of $M J \_A B S O L U T E$ except D_NONNORDIC, using a nearest-neighbor matching approach with a caliper constraint $(\leq .01)$ to construct matched pairs (Erkens \& Bonner, 2012). These propensity scores can be seen as the probability that a board has a non-Nordic director conditional on the observed covariates. The propensity scores form the basis to match firms that had a non-Nordic directors with firms that had the closest propensity as treatment firm, but chose not to include such a director on the board. In other words, we use a matched-pair research design that matches a treatment firm (i.e., a firm that has a nonNordic board member) with a control firm (i.e., a firm that does not have a non-Nordic board member) that is similar across all other observed covariates. The final sample includes 348 matched pairs.

Panels A and B of Table 6 report the comparison results pre- and post-PSM, respectively. The results show that, after the PSM procedure, the differences in mean and median values of the covariates for the treatment and control firms became small and insignificant, suggesting our matching procedure was reasonably successful.

\section{[Insert table 6 around here]}

More importantly, the results show that in both pre- and post-PSM comparisons firms with a nonNordic director have significantly higher levels of earnings management than firms without a nonNordic director, whereas (almost) all significant differences in other covariates between the two groups pre-PSM disappear with the propensity score matched pairs post-PSM. To summarize, our findings of the PSM-approach support the idea that, all other things being equal, the presence of a nonNordic board member is associated with higher levels of earnings management.

\subsection{Exploring the role of accounting knowledge and/or language}


Now that we have established that the presence of non-Nordic directors is associated with higher levels of earnings management, we will explore possible explanations for this effect.

First, we explore the role of accounting knowledge. As indicated in our literature review, recognizing possibly opportunistic accounting choices aimed at managing earnings require a high degree of knowledge of accounting rules (Dhaliwal et al., 2010). We expect that while non-Nordic directors may be less familiar with local accounting rules (Masulis et al., 2012), they are likely to possess more knowledge of International Financial Reporting Standards (IFRS) and/or US GAAP. Hence, the impact of the presence of non-Nordic directors on earnings management may depend on whether the firm draws up its financial statements using either local GAAP or IFRS. To explore this possibility we look at whether a firm in a specific year adopted local (i.e., Nordic) GAAP or IFRS. Specifically, using data from Datastream (with missing values collected from firms' annual reports), we construct an indicator variable, $L O C A L \_G A A P$, that equals 1 if the firm, in a specific year, adopted local accounting rules, and 0 if the firm adopted IFRS or US GAAP. We then created an interaction variable between $D \_N O N N O R D I C * L O C A L \_G A A P{ }^{i x}$

Untabulated results indicate that the use of local GAAP $(\beta=-0.021 ; \mathrm{p}<0.01)$ is negatively associated with the level of earnings management. This in line with the general notion that using IFRS offers more discretion to apply earnings management as compared to using local GAAP. Second, we show that the presence of a non-Nordic foreign board member is positively associated with earnings management $(\beta=0.030 ; p<0.01)$, which corroborates our previous findings with respect to this relationship. The interaction between local GAAP and the presence of a non-Nordic board member is also significant and negative $(\beta=-0.023, \mathrm{p}<0.10)$, indicating that the effect of non-Nordic board members on earnings management depends on the use of local GAAP or IFRS. Figure 1 suggests that levels of earnings management are higher for firms that use IFRS and have non-Nordic individuals on the board of directors. ${ }^{\mathrm{x}}$ In particular, it suggests that the negative association between using local GAAP and earnings management is less strong when non-Nordic individuals are on the board. This may be explained by the fact that these board members have less knowledge of local rules and regulations. At the same time, our result for the interaction term suggests that the positive association between using IFRS and earnings management is stronger when non-Nordic individuals sit on the 
board. This may reflect that these board members have more knowledge of the opportunities for earnings management under international accounting standards.

\section{[Insert figure 1 around here]}

To examine the role of language, we follow Brochet, Naranjo \& Yu (2013) and construct a LANGUAGE_DISTANCE variable. This variable uses the TOEFL scores (regarding average speaking proficiency in English in a country; a score ranging from 0 to 30, with higher scores indicating a higher level of proficiency in English) to measure the difficulty members from of a certain country experience when they have to speak in English. ${ }^{\mathrm{xi}}$ For instance, the TOEFL-score for Japan is about 16, while the U.S. and the U.K. score 30. Using this information, per board we construct the maximum distance from 30. For instance, if a Norwegian board contains a Japanese (TOEFL=16), a Dutch $(\mathrm{TOEFL}=25)$ and 3 Norwegian $(\mathrm{TOEFL}=24.5)$ individuals, the maximum score of LANGUAGE_DISTANCE for this board would be based on the Japanese individual (as this country scores lowest in terms of proficiency) and it would be 14. Moreover, if a board consisted of 12 members, 10 Swedish $($ TOEFL $=24.15)$ persons and 2 Irish folks, LANGUAGE_DISTANCE would be 5.85. Obviously, in a board without any foreigner the score on LANGUAGE_DISTANCE would be 0. Untabulated results reveal no statistically significant associations between LANGUAGE_DISTANCE and our proxy for earnings management. ${ }^{\text {xii, xiii }}$

\section{Conclusion and limitations}

This study investigates the association of the presence of foreign directors on earnings management using a sample of 3,249 firm-year observations representing about 586 non-financial listed Nordic firms during 2001-2008. We find that the presence of a non-Nordic foreign director (i.e., directors that do not have a Nordic background) rather than a foreign per se, is associated with significantly higher levels of earnings management. We find the same result if we use alternative measures for both the presence of a non-Nordic foreign director and earnings management. Moreover, we find evidence suggesting that the presence of a non-Nordic, foreign director is associated with income-increasing earnings management. We also deal with potential endogeneity issues by using an instrumental variables approach, as well as by applying propensity score matching, but this does not affect our main 
finding regarding the positive association between the presence of a non-Nordic foreign director the levels of earnings management. Finally, in this study we provide preliminary evidence that differences in accounting knowledge, rather than language-related factors, drive this effect.

These results suggest that foreign directors are less effective monitors. That is, they favor the interpretation that it may not necessarily be beneficial to appoint a foreign director to the board of directors as these directors experience monitoring deficiencies and, hence, are not effective in disciplining managers as far as earnings management is concerned.

As any study, ours is also subject to a number of caveats. First, we focus only on the firms headquartered in Nordic countries. Hence, it is possible that our results are not generalizable to other countries that have different regulatory institutions and are different in terms of linguistic features. Second, although we mitigate a possible endogeneity problem by our 2SLS-approach and by using PSM, as in many other studies on boards (Adams et al., 2010), we cannot rule out endogeneity completely. Therefore, we interpret the results in terms of associations rather than causal relationships. Third, any proxy of earnings management is subjected to potential measurement errors (Dechow et al., 2010). We have tried to mitigate this concern by showing the robustness of the results to an alternative proxy for earnings management.

Perhaps most importantly, however, we realize that our efforts to disentangle the effects of differences in accounting knowledge versus language-related factors at this stage may not be convincing enough. The measurement of both the differences in accounting knowledge and languagerelated factors remains rather general and indirect. Our measures may not properly describe the mechanisms by which lack of knowledge of local accounting standards and/or difficulties in communication due to language leads to higher levels of earnings management. Given the type of the data we have used (i.e. secondary data based on annual reports, websites, etc.), it seems perhaps difficult to open the black box of these mechanisms, however. Future research may have to consider more direct ways to measure accounting knowledge and language issues to open up this black box. We think that studies using vignettes or experiments combined with questionnaires to measure (local) financial (accounting) may be fruitful to advance our knowledge on how (local) accounting knowledge affects earnings quality in general and earnings management in particular. Another valuable way to 
open up the black box involves board room observations, i.e. video analyses of board meetings and/or board meeting participation studies.

Notwithstanding these caveats, our study represents an important step in understanding the impact of foreign directors on earnings management. 


\section{References}

Adams, R., \& Ferreira, D. 2009. Women in the boardroom and their impact on governance and performance. Journal of Financial Economics, 94(2): 291-309.

Adams, R.B., Hermalin, B.E., \& Weisbach, M.S. 2010. The role of boards of directors in corporate governance: A conceptual framework and survey. Journal of Economic Literature, 48(1): 58107.

Ahmed, A. \& Duellman, S. 2007. Accounting conservatism and board of director characteristics: An empirical analysis. Journal of Accounting and Economics, 43(2-3): 411-37.

Aiken, L. S., \& West, S. G. 1991. Multiple Regression: Testing and Interpreting Interactions. London: Sage.

Aisbitt, S. 2001. Measurement of harmony of financial reporting within and between countries: the case of the Nordic countries. European Accounting Review, 10(1): 51-72.

Aisbitt, S. 2002. Harmonisation of financial reporting before the European company law directives: the case of the Nordic Companies Act. Accounting and Business Research, 32(2): 105-117.

Armstrong, C.S., Guay, W.R., \& Weber, J.P. 2010. The role of information and financial reporting in corporate governance and debt contracting. Journal of Accounting \& Economics, 50(2-3):179234.

Armstrong, C.S., Jagolinzer, A.D. and Larcker, D.F. 2010. Chief Executive Officer equity incentives and accounting irregularities. Journal of Accounting Research, 48(2): 225-271.

Attig, N., Boubakri, N., El Ghoul, S., \& Guedhami, O. 2014. Firm internationalization and corporate social responsibility. Journal of Business Ethics, forthcoming.

Barth, M.E., Landsman, W.R., \& Lang, M.H., 2008. International accounting standards and accounting quality. Journal of Accounting Research, 46(3): 467-498.

Brochet, F., Naranjo, P., \& Yu, G. 2013. Capital market consequences of linguistic complexity in conference calls of non-U.S. firms. Harvard Business School Research Paper No. 2154948. Available at SSRN: http://ssrn.com/abstract=2154948.

Bruyneels, L. \& Cardinaels, E. 2014. The audit committee: Management watchdog or personal friend of the CEO. The Accounting Review, 89(1): 113-145. 
Caban-Garcia, M.T., \& He, H. 2013. Comparability of earnings in Scandinavian countries: The impact of mandatory IFRS adoption and stock exchange consolidations. Journal of International Accounting Research, 12(1): 55-76.

Chan, A.M.Y., Liu, G., \& Sun, J. 2013. Independent audit committee members’ board tenure and audit fees. Accounting and Finance, 53(4): 1129-1147.

Chen, G., Luo, S., Tang, Y., \& Tong, J.Y. 2014. Passing probation: Earnings management by interim CEOs and its effect on their promotion prospects. Academy of Management Journal, forthcoming.

Cheng, S. 2008. Board size and the variability of corporate performance. Journal of Financial Economics, 87(1): 157-76

Chiu, P-C., Teoh, S.H., \& Tian, F. 2013. Board interlocks and earnings management contagion. The Accounting Review, 88(3): 915-944.

Davidson, W.N., Jiraporn, P., \& Nemec, C. 2004. Earnings management following duality creating successions: Ethnostatistics, impression management, and agency theory. Academy of Management Journal, 47(2): 267-275.

Dechow, P.M., \& Dichev, I.D.. 2002. The quality of accruals and earnings: The role of accrual estimation errors. The Accounting Review, 77(Supplement): 35-59.

Dechow, P.M., Ge, W., \& Schrand, C. 2010. Understanding earnings quality: A review of the proxies, their determinants and their consequences. Journal of Accounting \& Economics, 50(2-3): 344401.

Dechow, P.M., R. G. Sloan, and A. P. Sweeney. 1995. Detecting earnings management. The Accounting Review, 70(2): 193-225.

Dhaliwal, D., Naiker, V., \& Navissi, F. 2010. The association between accruals quality and the characteristics of accounting experts and mix of expertise on audit committees. Contemporary Accounting Research, 27(3), 787-827.

Erkens, D.H., \& Bonner, S.E. 2012. The role of firm status in appointments of accounting financial experts to audit committees. The Accounting Review, 88(1): 107-36. 
Fama, E.F., \& Jensen, M.C. 1983. Separation of ownership and control. Journal of Law and Economics, 26(2): 301-25.

Forbes, D., \& Milliken, F. 1999. Cognition and corporate governance: Understanding boards of directors as strategic decision-making groups. Academy of Management Review, 24(3), 489-505.

García-Meca, E., \& Sánchez-Ballesta, J.P. 2009. Corporate governance and earnings management: A meta-analysis. Corporate Governance: An International Review, 17(5): 594-610.

Ghosh, D., \& Olsen, L. 2009. Environmental uncertainty and managers’ use of discretionary accruals. Accounting, Organizations \& Society, 34(2), 188-205.

Graham, J. R., Harvey, C. R., \& Rajgopal, S. 2005. The economic implications of corporate financial reporting. Journal of Accounting and Economics, 40(1): 3-73.

Healy, P.M. \& Wahlen, J.M. 1999. A review of the earnings management literature and its implications for standard setting. Accounting Horizons, 13(4): 365-383.

Hermalin, B., \& Weisbach, M., 2003. Boards of directors as an endogenously determined institution: A survey of the economic literature. FRBNY Economic Policy Review, 9(1): 7-26.

Hwang, B-H., \& Kim, S. 2009. It pays to have friends. Journal of Financial Economics, 93(1): 13858.

Jensen, M.C., \& Meckling, W. 1976. Theory of the firm: Managerial behavior, agency costs and ownership structure. Journal of Financial Economics, 3(4): 305-60.

Kassis-Henderson J. 2005. Language diversity in international management teams. International Studies of Management and Organization, 35(1): 43-54.

Kassis-Henderson J. 2010, Multilingual top management teams, in Bournois, F., Duval-Hamel, J., Roussillon, S., \& and Scaringella, J-L. (eds.), Handbook of Top Management Teams, Basingstoke (UK): Palgrave MacMillan, pp 421-427.

Katz, S.P. 2009. Earnings quality and ownership structure: The role of private equity sponsors. The Accounting Review, 84(3): 623-658.

Klein, A. 2002. Audit committee, board of director characteristics, and earnings management. Journal of Accounting and Economics, 33(3): 375-400. 
Krishnan, G., \& Visvanathan, G. 2008. Does the SOX definition of an accounting expert matter? The association between audit committee directors' accounting expertise and accounting conservatism. Contemporary Accounting Research 82(3): 827-858.

Lang, M., Raedy, J., \& Yetman, M. 2003. How representative are cross-listed firms? An analysis of firm and accounting quality. Journal of Accounting Research, 41(2): 363-386.

Larcker, D.F., Richardson, S., \& Tuna, I. 2007. Corporate governance, accounting outcomes, and organizational performance. The Accounting Review 82(4): 963-1008.

Larcker, D.F., \& Rusticus, T.O. 2010. On the use of instrumental variables in accounting research. Journal of Accounting \& Economics, 49(3): 186-205.

Lennox, C.S., Francis, J.R., \& Wang, Z. 2012. Selection models in accounting research. The Accounting Review, 87(2): 589-616.

Lewis, P.M. 2009. Ethnologue: Languages of the World. 16th edition. Dallas Texas, SIL International. Marra, A, Mazzola, P., \& Prencipe, A. 2011. Board monitoring and earnings management pre- and post-IFRS. The International Journal of Accounting, 46 (2): 205-230.

Masulis, R.W., Wang, C., \& Xie, F. 2012. Globalizing the boardroom—The effects of foreign directors on corporate governance and firm performance. Journal of Accounting \& Economics, 53(3): 527-554.

Nam, D., Park, H.D., \& Arthurs, J.D. 2014. Looking attractive until you sell: Earnings management, lockup expiration, and venture capitalists. Journal of Management Studies, 51(8): 1286-1310.

OECD, 2004. OECD principles of corporate governance. OECD Publications Service, Paris.

Oxelheim, L., \& Clarkson, K., 2014. Cronyism and the determinants of chairman compensation. Journal of Business Ethics, forthcoming.

Oxelheim, L. Gregorič, A., Randøy, T., \& Thomsen, S. 2013. On the internationalization of corporate boards: The case of Nordic firms. Journal of International Business Studies, 44(3): 173-194.

Oxelheim, L., \& Randøy, T. 2003. The impact of foreign board membership on firm value. Journal of Banking \& Finance, 27 (12): 2369-2392.

Oxelheim, L., \& Randøy, T. 2005. The Anglo-American financial influence on CEO compensation in non-Anglo-American firms. Journal of International Business Studies, 36(4): 470-483. 
Peek, E., Meuwissen, R., Moers, F., \& Vanstraelen, A. 2013, Comparing abnormal accruals estimates across samples: An international test. European Accounting Review, 22(3): 533-572.

Peasnell, K.V., Pope, P.F., \& Young, S. 2005. Board monitoring and earnings management: Do outside directors influence abnormal accruals? Journal of Business Finance \& Accounting, 32(78): 1311-46.

Petersen, M.A., 2009. Estimating standard errors in finance panel data sets: comparing approaches. Review of Financial Studies, 22(1), 435-480.

Piekkari, R., Oxelheim, L., \& Randøy, T. 2015. The silent board: How language diversity may influence the work processes of corporate boards. Corporate Governance: An International Review, 23(1): 25-41.

Ruigrok, W., Peck, S., \& Tacheva, S. 2007. Nationality and gender diversity on Swiss corporate boards. Corporate Governance: An International Review, 15(4): 546-557

Shi, Y., Magnan, M., \& Kim, J-B. 2012. Do countries matter for voluntary disclosure? Evidence from cross-listed firms in the US. Journal of International Business Studies, 43(2): 143-165.

Sinani, E., Stafsudd, A., Thomsen, S., Edling, C., \& Randøy, T. 2008. Corporate governance in Scandinavia: comparing networks and formal institutions. European Management Review, 5(1): 27-40.

Srinidhi, B., Gul, F.A., \& Tsu, J. 2011. Female directors and earnings quality. Contemporary Accounting Research, 28(5): 1610-1644.

Tenzer, H., Pudelko, M., \& Harzing, A.W. 2014. The impact of language barriers on trust formation in multinational teams. Journal of International Business Studies, 45(5): 508-535.

White, H., 1980. A heteroskedasticity-consistent covariance matrix estimator and a direct test for heteroskedasticity. Econometrica, 48(4), 817-838.

Xie, B., Davidson III, W.N., \& DaDalt, P.J. 2003. Earnings management and corporate governance: The role of the board and the audit committee. Journal of Corporate Finance, 9(3): 295-316.

Zhang, Y., Zhou, J., \& Zhou, N. 2007. Audit committee quality, auditor independence, and internal control weaknesses. Journal of Accounting and Public Policy 26(3): 300-327. 
Table 1: Descriptive statistics and correlations

Panel A: Full sample

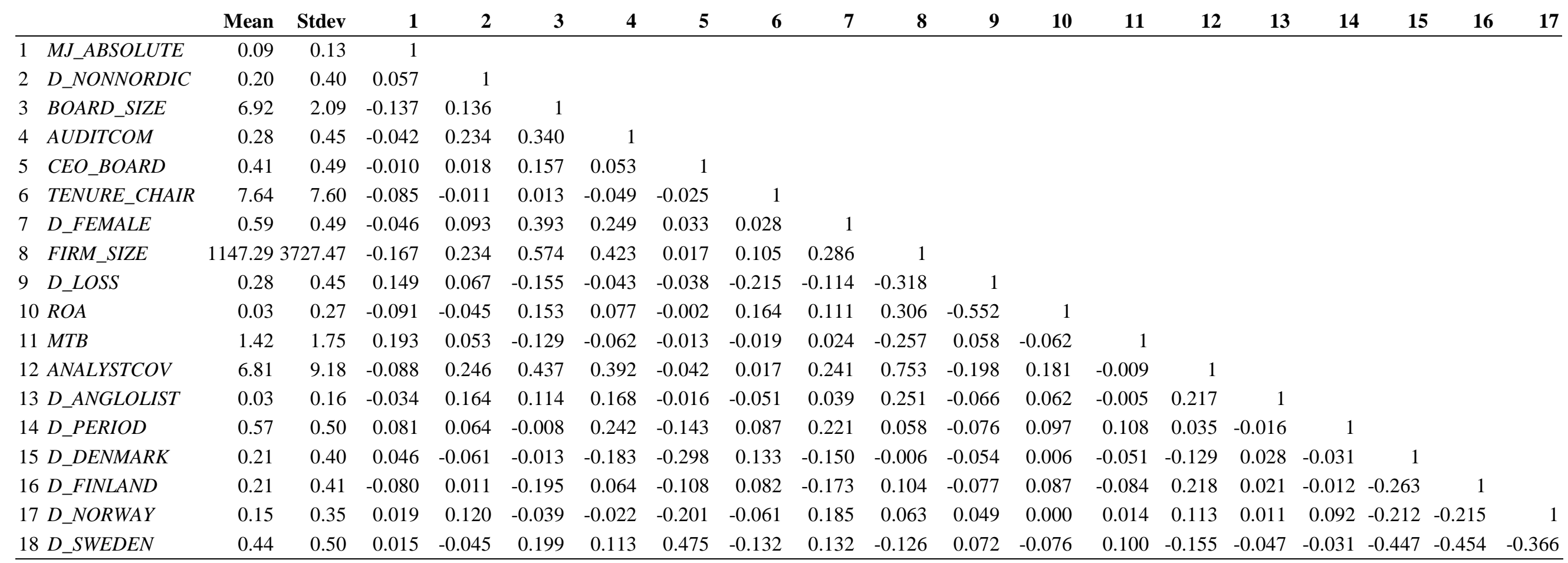

Note: $N=3,249$. All (Pearson) correlations higher than (the absolute value of) 0.035 are statistically significant at the 5\%-level. FIRM_SIZE is in $€ m$. 
Panel B: Breakdown per country

\begin{tabular}{lrrrr} 
& Denmark & Finland & Norway & Tweden \\
\cline { 2 - 5 } Number of Obs. & 668 & 685 & 480 & 1,416 \\
D_NONNORDIC & 0.151 & 0.207 & 0.315 & 0.179 \\
MJ_ABS & 0.105 & 0.073 & 0.099 & 0.199
\end{tabular}

Panel C: Breakdown per year

\begin{tabular}{lrrrrrrrrr} 
& $\mathbf{2 0 0 1}$ & $\mathbf{2 0 0 2}$ & $\mathbf{2 0 0 3}$ & $\mathbf{2 0 0 4}$ & $\mathbf{2 0 0 5}$ & $\mathbf{2 0 0 6}$ & $\mathbf{2 0 0 7}$ & $\mathbf{2 0 0 8}$ & Total \\
\cline { 2 - 7 } Number of Obs. & 295 & 340 & 365 & 396 & 418 & 485 & 494 & 456 & 3,249 \\
D_NONNORDIC & 0.169 & 0.144 & 0.167 & 0.194 & 0.201 & 0.208 & 0.235 \\
MJ_ABS & 0.085 & 0.080 & 0.077 & 0.082 & 0.112 & 0.107 & 0.105
\end{tabular}

Note: Panels B and C provide a breakdown of the main variables per country and per year. The numbers represent mean values. 
Table 2: Regression analysis of impact of foreign directors on earnings management

\begin{tabular}{|c|c|c|}
\hline & (1) & (2) \\
\hline D_FOREIGN & $\begin{array}{c}0.010 \\
{[0.007]}\end{array}$ & \\
\hline D_NONNORDIC & & $\begin{array}{l}0.022 \\
{[0.009]^{* *}}\end{array}$ \\
\hline BOARD_SIZE & $\begin{array}{l}-0.043 \\
{[0.014]^{* * *}}\end{array}$ & $\begin{array}{l}-0.043 \\
{[0.014]^{* * *}}\end{array}$ \\
\hline AUDITCOM & $\begin{array}{l}0.002 \\
{[0.008]}\end{array}$ & $\begin{array}{l}-0.000 \\
{[0.008]}\end{array}$ \\
\hline CEO_BOARD & $\begin{array}{l}0.013 \\
{[0.008]}\end{array}$ & $\begin{array}{l}0.012 \\
{[0.008]}\end{array}$ \\
\hline TENURE_CHAIR & $\begin{array}{l}-0.009 \\
{[0.003]^{* * *}}\end{array}$ & $\begin{array}{l}-0.010 \\
{[0.003]^{* * *}}\end{array}$ \\
\hline D_FEMALE & $\begin{array}{l}-0.004 \\
{[0.007]}\end{array}$ & $\begin{array}{l}-0.004 \\
{[0.007]}\end{array}$ \\
\hline FIRM_SIZE & $\begin{array}{l}-0.006 \\
{[0.008]}\end{array}$ & $\begin{array}{l}-0.006 \\
{[0.008]}\end{array}$ \\
\hline D_LOSS & $\begin{array}{l}0.032 \\
{[0.008]^{* * *}}\end{array}$ & $\begin{array}{l}0.031 \\
{[0.007]^{* * *}}\end{array}$ \\
\hline$R O A$ & $\begin{array}{l}0.007 \\
{[0.010]}\end{array}$ & $\begin{array}{l}0.008 \\
{[0.010]}\end{array}$ \\
\hline MTB & $\begin{array}{l}0.011 \\
{[0.002]^{* * *}}\end{array}$ & $\begin{array}{l}0.011 \\
{[0.002]^{* * *}}\end{array}$ \\
\hline ANALYSTCOV & $\begin{array}{l}0.006 \\
{[0.009]}\end{array}$ & $\begin{array}{l}0.005 \\
{[0.009]}\end{array}$ \\
\hline D_ANGLOLIST & $\begin{array}{l}-0.012 \\
{[0.013]}\end{array}$ & $\begin{array}{l}-0.015 \\
{[0.013]}\end{array}$ \\
\hline D_PERIOD & $\begin{array}{l}0.022 \\
{[0.005]^{* * *}}\end{array}$ & $\begin{array}{l}0.022 \\
{[0.005]^{* * *}}\end{array}$ \\
\hline INTERCEPT & $\begin{array}{l}0.171 \\
{[0.063]^{* * *}}\end{array}$ & $\begin{array}{l}0.174 \\
{[0.063]^{* * *}}\end{array}$ \\
\hline COUNTRY & YES & YES \\
\hline INDUSTRY & YES & YES \\
\hline$R^{2}$ & 0.09 & 0.09 \\
\hline$N$ & 3,249 & 3,249 \\
\hline \multicolumn{3}{|c|}{$\begin{array}{l}\text { Notes } \\
\text { Dependent variable is the absolute value of the discretionary accruals based on the Modified Jones } \\
\text { model. See Appendix for variable definitions. In brackets are the standard errors adjusted for } \\
\text { heteroskedasticity (White, } 1980 \text { ) and firm clustering (Petersen, 2009). } \\
* * *, * * \text {, and * denote significance at the } 0.01,0.05 \text {, and } 0.10 \text { levels (two-tailed), respectively. }\end{array}$} \\
\hline
\end{tabular}


Table 3: Robustness checks using alternative proxies for board internationalization

\begin{tabular}{|c|c|c|}
\hline & (1) & (2) \\
\hline D_NONNORDIC2 & $\begin{array}{c}0.024 \\
{[0.011]^{* *}}\end{array}$ & \\
\hline PERC_NONNORDIC & & $\begin{array}{c}0.068 \\
{[0.030]^{* *}}\end{array}$ \\
\hline BOARD_SIZE & $\begin{array}{l}-0.045 \\
{[0.014]^{* * *}}\end{array}$ & $\begin{array}{l}-0.042 \\
{[0.014]^{* * *}}\end{array}$ \\
\hline AUDITCOM & $\begin{array}{l}-0.000 \\
{[0.008]}\end{array}$ & $\begin{array}{l}-0.001 \\
{[0.008]}\end{array}$ \\
\hline CEO_BOARD & $\begin{array}{c}0.012 \\
{[0.008]}\end{array}$ & $\begin{array}{c}0.012 \\
{[0.008]}\end{array}$ \\
\hline TENURE_CHAIR & $\begin{array}{l}-0.010 \\
{[0.003]^{* * *}}\end{array}$ & $\begin{array}{l}-0.009 \\
{[0.003]^{* * *}}\end{array}$ \\
\hline D_FEMALE & $\begin{array}{l}-0.003 \\
{[0.006]}\end{array}$ & $\begin{array}{l}-0.004 \\
{[0.007]}\end{array}$ \\
\hline FIRM_SIZE & $\begin{array}{l}-0.005 \\
{[0.008]}\end{array}$ & $\begin{array}{l}-0.005 \\
{[0.008]}\end{array}$ \\
\hline D_LOSS & $\begin{array}{c}0.032 \\
{[0.008]^{* * *}}\end{array}$ & $\begin{array}{c}0.031 \\
{[0.008]^{* * *}}\end{array}$ \\
\hline$R O A$ & $\begin{array}{c}0.006 \\
{[0.010]}\end{array}$ & $\begin{array}{c}0.006 \\
{[0.010]}\end{array}$ \\
\hline MTB & $\begin{array}{c}0.011 \\
{[0.002]^{* * *}}\end{array}$ & $\begin{array}{c}0.011 \\
{[0.002]^{* * *}}\end{array}$ \\
\hline ANALYSTCOV & $\begin{array}{c}0.006 \\
{[0.009]}\end{array}$ & $\begin{array}{c}0.005 \\
{[0.009]}\end{array}$ \\
\hline D_ANGLOLIST & $\begin{array}{l}-0.017 \\
{[0.012]}\end{array}$ & $\begin{array}{l}-0.016 \\
{[0.012]}\end{array}$ \\
\hline D_PERIOD & $\begin{array}{c}0.022 \\
{[0.005]^{* * *}}\end{array}$ & $\begin{array}{c}0.022 \\
{[0.005]^{* * *}}\end{array}$ \\
\hline INTERCEPT & $\begin{array}{c}0.173 \\
{[0.061]^{* * *}}\end{array}$ & $\begin{array}{c}0.165 \\
{[0.062]^{* * *}}\end{array}$ \\
\hline $\begin{array}{l}R^{2} \\
N\end{array}$ & $\begin{array}{l}0.09 \\
3,249\end{array}$ & $\begin{array}{l}0.09 \\
3,249\end{array}$ \\
\hline \multicolumn{3}{|c|}{$\begin{array}{l}\text { Notes } \\
\text { Dependent variable is the absolute value of the discretionary accruals based on } \\
\text { the Modified Jones model. } D \text { _NONNORDIC2 is an indicator variable equal to } 1 \\
\text { if the board has two or more non-Nordic foreigners on the board of directors; and } \\
\text { zero otherwise. PERC_NONNORDIC equals the percentage of non-Nordic } \\
\text { directors in the board. See Appendix for all other variable definitions. In brackets } \\
\text { are the standard errors adjusted for heteroskedasticity (White, 1980) and firm } \\
\text { clustering (Petersen, 2009). Country and industry fixed effects are suppressed for } \\
\text { brevity. } \\
* * *, * * \text {, and * denote significance at the } 0.01,0.05 \text {, and } 0.10 \text { levels (two-tailed), } \\
\text { respectively }\end{array}$} \\
\hline
\end{tabular}


Table 4: Regression analysis based on signed accruals

\begin{tabular}{|c|c|c|c|}
\hline & $\begin{array}{c}\text { (1) } \\
\text { Full sample }\end{array}$ & $\begin{array}{l}\quad(2) \\
\text { Income- } \\
\text { increasing }\end{array}$ & $\begin{array}{l}\text { (3) } \\
\text { Income- } \\
\text { decreasing }\end{array}$ \\
\hline D_NONNORDIC & $\begin{array}{c}0.018 \\
{[0.008]^{* *}}\end{array}$ & $\begin{array}{c}0.037 \\
{[0.014]^{* * *}}\end{array}$ & $\begin{array}{c}0.009 \\
{[0.008]}\end{array}$ \\
\hline BOARD_SIZE & $\begin{array}{c}0.014 \\
{[0.012]}\end{array}$ & $\begin{array}{l}-0.023 \\
{[0.013]^{*}}\end{array}$ & $\begin{array}{l}-0.065 \\
{[0.020]^{* * *}}\end{array}$ \\
\hline AUDITCOM & $\begin{array}{c}0.000 \\
{[0.007]}\end{array}$ & $\begin{array}{l}-0.003 \\
{[0.011]}\end{array}$ & $\begin{array}{c}0.002 \\
{[0.008]}\end{array}$ \\
\hline CEO_BOARD & $\begin{array}{c}0.007 \\
{[0.007]}\end{array}$ & $\begin{array}{c}0.022 \\
{[0.013]^{*}}\end{array}$ & $\begin{array}{c}0.003 \\
{[0.007]}\end{array}$ \\
\hline TENURE_CHAIR & $\begin{array}{c}0.002 \\
{[0.003]}\end{array}$ & $\begin{array}{l}-0.011 \\
{[0.004]^{* * *}}\end{array}$ & $\begin{array}{l}-0.009 \\
{[0.004]^{* *}}\end{array}$ \\
\hline D_FEMALE & $\begin{array}{c}0.004 \\
{[0.006]}\end{array}$ & $\begin{array}{l}-0.006 \\
{[0.009]}\end{array}$ & $\begin{array}{l}-0.001 \\
{[0.008]}\end{array}$ \\
\hline FIRM_SIZE & $\begin{array}{l}-0.013 \\
{[0.008]}\end{array}$ & $\begin{array}{l}-0.010 \\
{[0.011]}\end{array}$ & $\begin{array}{c}0.001 \\
{[0.010]}\end{array}$ \\
\hline D_LOSS & $\begin{array}{l}-0.031 \\
{[0.008]^{* * *}}\end{array}$ & $\begin{array}{c}0.033 \\
{[0.014]^{* *}}\end{array}$ & $\begin{array}{c}0.033 \\
{[0.008]^{* * *}}\end{array}$ \\
\hline$R O A$ & $\begin{array}{l}0.040 \\
{[0.016]^{* *}}\end{array}$ & $\begin{array}{c}0.027 \\
{[0.016]^{*}}\end{array}$ & $\begin{array}{l}-0.009 \\
{[0.015]}\end{array}$ \\
\hline MTB & $\begin{array}{c}0.001 \\
{[0.002]}\end{array}$ & $\begin{array}{l}0.019 \\
{[0.003]^{* * *}}\end{array}$ & $\begin{array}{l}0.006 \\
{[0.002]^{* * *}}\end{array}$ \\
\hline ANALYSTCOV & $\begin{array}{l}-0.003 \\
{[0.009]}\end{array}$ & $\begin{array}{l}-0.002 \\
{[0.012]}\end{array}$ & $\begin{array}{c}0.008 \\
{[0.012]}\end{array}$ \\
\hline D_ANGLOLIST & $\begin{array}{l}-0.024 \\
{[0.015]}\end{array}$ & $\begin{array}{l}-0.033 \\
{[0.012]^{* * *}}\end{array}$ & $\begin{array}{c}0.006 \\
{[0.020]}\end{array}$ \\
\hline D_PERIOD & $\begin{array}{l}-0.006 \\
{[0.005]}\end{array}$ & $\begin{array}{c}0.030 \\
{[0.008]^{* * *}}\end{array}$ & $\begin{array}{c}0.017 \\
{[0.006]^{* * *}}\end{array}$ \\
\hline INTERCEPT & $\begin{array}{c}0.068 \\
{[0.052]}\end{array}$ & $\begin{array}{c}0.188 \\
{[0.081]^{* *}}\end{array}$ & $\begin{array}{c}0.149 \\
{[0.068]^{* *}}\end{array}$ \\
\hline COUNTRY & YES & YES & YES \\
\hline INDUSTRY & YES & YES & YES \\
\hline$R^{2}$ & 0.02 & 0.11 & 0.11 \\
\hline$N$ & 3,249 & 1,640 & 1,609 \\
\hline
\end{tabular}

Notes

In columns (1) and (2) the dependent variable is the value of the discretionary accruals based on the Modified Jones model. In column (3) the dependent variable is the value of the discretionary accruals based on the Modified Jones model multiplied by -1 . See Appendix for all other variable definitions. In brackets are the standard errors adjusted for heteroskedasticity (White, 1980) and firm clustering (Petersen, 2009). Country and industry fixed effects are suppressed for brevity.

$* * *, * *$, and * denote significance at the $0.01,0.05$, and 0.10 levels (twotailed), respectively 
Table 5: 2SLS regressions of impact of foreign directors on earnings management

\begin{tabular}{|c|c|}
\hline Panel A: First stage of 2SI & \\
\hline PERC_FOREIGN_SALES & $\begin{array}{l}0.612 \\
{[0.239]^{* *}}\end{array}$ \\
\hline DISTANCE_TO_AIRPORT & $\begin{array}{l}0.282 \\
{[0.161]^{*}}\end{array}$ \\
\hline BOARD_SIZE & $\begin{array}{l}0.069 \\
{[0.275]}\end{array}$ \\
\hline AUDITCOM & $\begin{array}{l}0.361 \\
{[0.126]^{* * *}}\end{array}$ \\
\hline CEO_BOARD & $\begin{array}{l}0.271 \\
{[0.149]^{*}}\end{array}$ \\
\hline TENURE_CHAIR & $\begin{array}{l}0.023 \\
{[0.079]}\end{array}$ \\
\hline D_FEMALE & $\begin{array}{l}0.058 \\
{[0.142]}\end{array}$ \\
\hline FIRM_SIZE & $\begin{array}{l}0.154 \\
{[0.169]}\end{array}$ \\
\hline D_LOSS & $\begin{array}{l}0.394 \\
{[0.133]^{* * *}}\end{array}$ \\
\hline$R O A$ & $\begin{array}{l}-0.303 \\
{[0.196]}\end{array}$ \\
\hline MTB & $\begin{array}{l}0.084 \\
{[0.042]^{* *}}\end{array}$ \\
\hline ANALYSTCOV & $\begin{array}{l}0.193 \\
{[0.237]}\end{array}$ \\
\hline D_ANGLOLIST & $\begin{array}{l}0.357 \\
{[0.381]}\end{array}$ \\
\hline D_PERIOD & $\begin{array}{l}0.047 \\
{[0.092]}\end{array}$ \\
\hline INTERCEPT & $\begin{array}{l}-3.216 \\
{[1.486]^{* *}}\end{array}$ \\
\hline INDUSTRY & YES \\
\hline COUNTRY & YES \\
\hline (Pseudo) $\mathrm{R}^{2}$ & 0.125 \\
\hline Partial F-statistic & $16.024 * * *$ \\
\hline Partial $R$-statistic & 0.017 \\
\hline
\end{tabular}

Table continues on the next page 


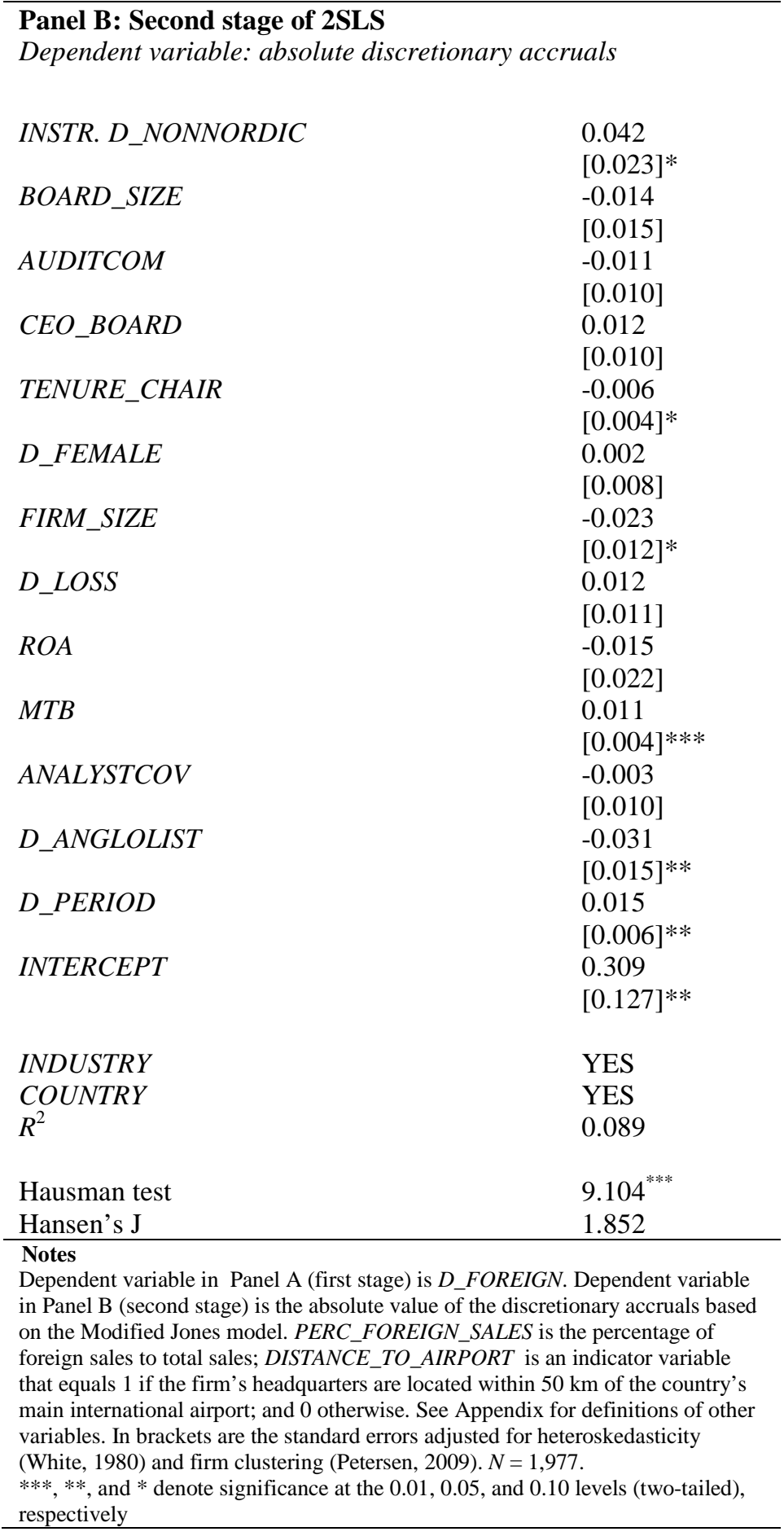


Table 6. Comparison between firms with non-Nordic board member and firms without non-Nordic board member, using propensity score matching (PSM)

Panel A: Pre-PSM, differences in earnings management and covariates across two groups based on D_NONNORDIC

\begin{tabular}{|c|c|c|c|c|c|c|c|c|}
\hline \multirow{2}{*}{ Variable } & \multicolumn{3}{|c|}{$\begin{array}{c}D \_N O N N O R D I C=1 \\
(\mathrm{n}=647)\end{array}$} & \multicolumn{3}{|c|}{$\begin{array}{c}D \_N O N N O R D I C=0 \\
(\mathrm{n}=2,602)\end{array}$} & \multicolumn{2}{|c|}{ Difference } \\
\hline & Mean & Median & Std. Dev. & Mean & Median & Std. Dev. & Mean & Median \\
\hline MJ_ABSOLUTE & 0.108 & 0.061 & 0.188 & 0.089 & 0.055 & 0.112 & $0.019 * * *$ & $0.006^{*}$ \\
\hline BOARD_SIZE & 7.535 & 7.000 & 2.313 & 6.772 & 7.000 & 2.005 & $0.763^{* * *}$ & $0.000 * * *$ \\
\hline AUDITCOM & 0.496 & 0.000 & 0.500 & 0.232 & 0.000 & 0.422 & $0.264 * * *$ & $0.000 * * *$ \\
\hline CEO_BOARD & 0.428 & 0.000 & 0.495 & 0.406 & 0.000 & 0.491 & 0.022 & 0.000 \\
\hline TENURE_CHAIR & 7.699 & 5.000 & 9.173 & 7.626 & 5.000 & 7.154 & 0.073 & 0.000 \\
\hline D_FEMALE & 0.682 & 1.000 & 0.466 & 0.566 & 1.000 & 0.496 & $0.115^{* * *}$ & $0.000 * * *$ \\
\hline FIRM_SIZE (in $€ m)$ & $2,718.033$ & 395.048 & $5,894.770$ & 756.717 & 88.174 & $2,820.199$ & $1,961.317^{* * *}$ & $306.873^{* * *}$ \\
\hline D_LOSS & 0.338 & 0.000 & 0.474 & 0.263 & 0.000 & 0.440 & $0.075^{* * *}$ & $0.000 * * *$ \\
\hline$R O A$ & 0.002 & 0.065 & 0.282 & 0.032 & 0.074 & 0.266 & $-0.030 * * *$ & $-0.009 * * *$ \\
\hline MTB & 1.605 & 0.934 & 2.143 & 1.374 & 0.904 & 1.629 & $0.231^{* * *}$ & $0.030 *$ \\
\hline ANALYSTCOV & 11.895 & 8.000 & 12.840 & 5.546 & 3.000 & 7.499 & $6.349 * * *$ & $5.000 * * *$ \\
\hline D_ANGLOLIST & 0.080 & 0.000 & 0.272 & 0.014 & 0.000 & 0.117 & $0.067 * * *$ & $0.000 * * *$ \\
\hline D_PERIOD & 0.634 & 1.000 & 0.482 & 0.555 & 1.000 & 0.497 & $0.079 * * *$ & $0.000 * * *$ \\
\hline
\end{tabular}

Two-sample $t$-tests are used to test the differences in means, and Wilcoxon two-sample rank-sum tests are used to test differences in medians 
Panel B: Post-PSM, differences in earnings management and covariates across two groups based on D_NONNORDIC

\begin{tabular}{|c|c|c|c|c|c|c|c|c|}
\hline \multirow{2}{*}{ Variable } & \multicolumn{3}{|c|}{$\begin{array}{c}D \_N O N N O R D I C=1 \\
(\mathrm{n}=348)\end{array}$} & \multicolumn{3}{|c|}{$\begin{array}{c}D \_N O N N O R D I C=0 \\
(\mathrm{n}=348)\end{array}$} & \multicolumn{2}{|c|}{ Difference } \\
\hline & Mean & Median & Std. Dev. & Mean & Median & Std. Dev. & Mean & Median \\
\hline MJ_ABSOLUTE & 0.107 & 0.060 & 0.163 & 0.077 & 0.046 & 0.115 & $0.029 * * *$ & $0.014 * * *$ \\
\hline BOARD_SIZE & 7.161 & 7.000 & 2.214 & 7.207 & 7.000 & 2.096 & -0.046 & 0.000 \\
\hline AUDITCOM & 0.348 & 0.000 & 0.477 & 0.391 & 0.000 & 0.489 & -0.043 & 0.000 \\
\hline CEO_BOARD & 0.371 & 0.000 & 0.484 & 0.422 & 0.000 & 0.495 & -0.052 & 0.000 \\
\hline TENURE_CHAIR & 7.655 & 5.000 & 8.803 & 7.601 & 5.000 & 6.670 & 0.055 & 0.000 \\
\hline D_FEMALE & 0.612 & 1.000 & 0.488 & 0.618 & 1.000 & 0.487 & -0.006 & 0.000 \\
\hline FIRM_SIZE (in €m) & $1,482.073$ & 182.771 & $3,690.652$ & $1,342.642$ & 200.698 & $4,056.292$ & 139.431 & -17.927 \\
\hline$D \_L O S S$ & 0.307 & 0.000 & 0.462 & 0.279 & 0.000 & 0.449 & 0.029 & 0.000 \\
\hline$R O A$ & -0.004 & 0.066 & 0.302 & 0.031 & 0.081 & 0.387 & -0.036 & $-0.015^{* *}$ \\
\hline MTB & 1.534 & 0.907 & 1.815 & 1.446 & 0.994 & 1.648 & 0.088 & -0.088 \\
\hline ANALYSTCOV & 8.526 & 5.000 & 10.063 & 7.879 & 5.000 & 8.763 & 0.647 & 0.000 \\
\hline D_ANGLOLIST & 0.037 & 0.000 & 0.190 & 0.026 & 0.000 & 0.159 & 0.011 & 0.000 \\
\hline D_PERIOD & 0.612 & 1.000 & 0.488 & 0.647 & 1.000 & 0.479 & -0.034 & 0.000 \\
\hline
\end{tabular}

Paired $t$-tests are used to test the differences in means and Wilcoxon matched pairs signed-rank tests are used to test differences in medians 
Figure 1: Interaction effect of $L O C A L \_G A A P$ and D_NONNORDIC

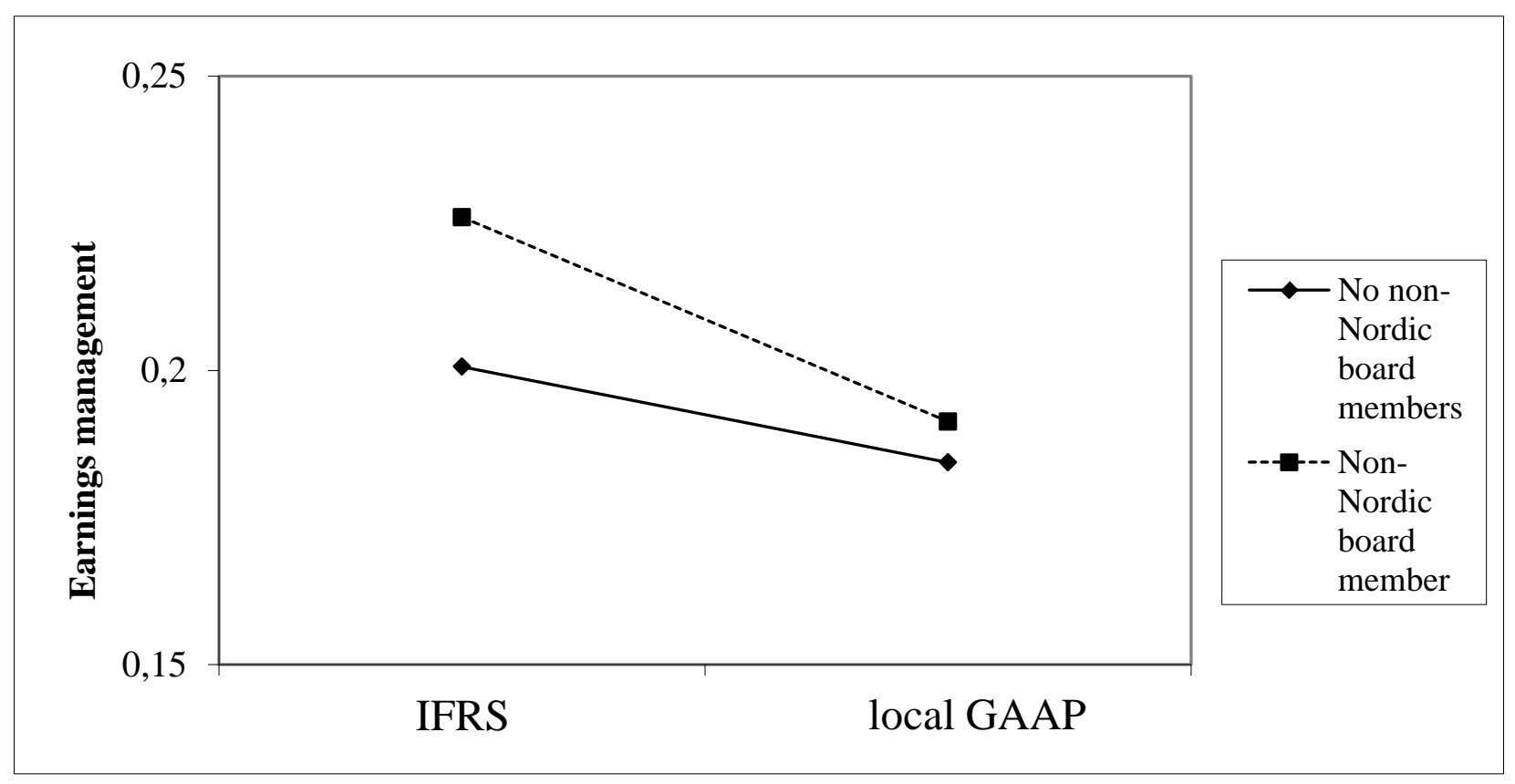




\section{Appendix: Variable definitions}

\begin{tabular}{|c|c|}
\hline Variable name & Definition \\
\hline \multicolumn{2}{|l|}{ In main tests } \\
\hline MJ_ABSOLUTE & $\begin{array}{l}\text { Absolute value of firms } i \text { 's residuals in } t \text { from a periodical cross- } \\
\text { sectional estimations of the Dechow et al. (1995) model. }\end{array}$ \\
\hline D_FOREIGN & $\begin{array}{l}\text { Indicator variable which assumes the value of one if at least one } \\
\text { foreigner is present on the board of directors; and zero otherwise. }\end{array}$ \\
\hline D_NONNORDIC & $\begin{array}{l}\text { Indicator variable which assumes the value of one if at least one non- } \\
\text { Nordic foreigner is present on the board of directors; and zero otherwise. }\end{array}$ \\
\hline BOARD_SIZE & The logarithm of the number of directors. \\
\hline AUDITCOM & $\begin{array}{l}\text { Indicator variable which assumes the value of one if there is a separate } \\
\text { audit committee; and zero otherwise. }\end{array}$ \\
\hline CEO_BOARD & $\begin{array}{l}\text { Indicator variable which assumes the value of one if the CEO sits on the } \\
\text { board of directors; and zero otherwise. }\end{array}$ \\
\hline TENURE_CHAIR & $\begin{array}{l}\text { The logarithm of the number of years the incumbent chairman served as } \\
\text { chairman. }\end{array}$ \\
\hline D_FEMALE & $\begin{array}{l}\text { Indicator variable which assumes the value of one if the board of } \\
\text { directors includes at least one female, and zero otherwise. }\end{array}$ \\
\hline FIRM_SIZE & $\begin{array}{l}\text { The logarithm of the firm's total assets in constant year- } 2000 \text { prices (in } \\
\text { million euros). }\end{array}$ \\
\hline D_LOSS & $\begin{array}{l}\text { Indicator variable which assumes the value of one if the firm reported a } \\
\text { loss, and zero otherwise. }\end{array}$ \\
\hline$R O A$ & Return on assets, defined as EBIT divided by total assets. \\
\hline MTB & $\begin{array}{l}\text { The ratio of the market value of the firm to the book value of total } \\
\text { assets. }\end{array}$ \\
\hline ANALYSTCOV & $\begin{array}{l}\text { The logarithm of one plus the number of financial analysts following the } \\
\text { firm (as reported in the } I / B / E / S \text { database). }\end{array}$ \\
\hline D_ANGLOLIST & $\begin{array}{l}\text { Indicator variable which assumes the value of one if the firm's shares } \\
\text { are cross-listed in the U.S., and zero otherwise. }\end{array}$ \\
\hline D_PERIOD & $\begin{array}{l}\text { Indicator variable which assumes the value of one for post-IFRS-years } \\
\text { (i.e., } 2005 \text { to 2008), and zero otherwise. }\end{array}$ \\
\hline \multicolumn{2}{|l|}{ In robustness checks } \\
\hline PERC_FOREIGN_SALES & The percentage of foreign sales to total sales. \\
\hline DISTANCE_TO_AIRPORT & $\begin{array}{l}\text { Indicator variable which assumes the value of } 1 \text { if the firm's } \\
\text { headquarters are located within } 50 \mathrm{~km} \text { of the country's main } \\
\text { international airport; and } 0 \text { otherwise. }\end{array}$ \\
\hline CHAIR_NONNORDIC & $\begin{array}{l}\text { Indicator variable which assumes the value of one if the chairperson is a } \\
\text { Non-Nordic foreigner; and zero otherwise. }\end{array}$ \\
\hline CHAIR_ANGLO & $\begin{array}{l}\text { Indicator variable which assumes the value of one if the chairperson is } \\
\text { an Anglo-American individual; and zero otherwise. }\end{array}$ \\
\hline D_NONNORDIC2 & $\begin{array}{l}\text { Indicator variable which assumes the value of one if at least two non- } \\
\text { Nordic foreigners are present on the board of directors; and zero } \\
\text { otherwise. }\end{array}$ \\
\hline PERC_NONNORDIC & Percentage of non-Nordic foreign directors on the board of directors. \\
\hline
\end{tabular}


${ }^{\mathrm{i}}$ Following Forbes and Milliken (1999: 493) cohesiveness refers to "the degree to which board members are attracted to each other and are motivated to stay on the board. [...] Cohesiveness captures the affective dimension of members' inclusion on the board and reflects the ability of the board to continue working together”.

${ }^{\text {ii }}$ Indeed, Barth, Landsman \& Lang (2008) show that firms adopting IFRS show an improvement in reporting quality in terms of earnings management, timely loss recognition, and value relevance. Moreover, Marra, Mazzola \& Pencipe (2011) find that the (negative) association between board independence and audit committee presence, on the one hand, and earnings management, on the other, is stronger in the postIFRS period than in the pre-IFRS period. They attribute this effect to the higher level of disclosure and transparency inherent in IFRS, which according to Marra et al. (2011) makes it easier for directors to identify and monitor the accounting policies applied by the firm.

iii To secure data validity, we verified the identification of foreigners using BoardEx (for the largest companies), Bloomberg’s Executive Profile \& Biography, Forbes, tax-related information (when publicly available) and other web-based sources such as Wikipedia.

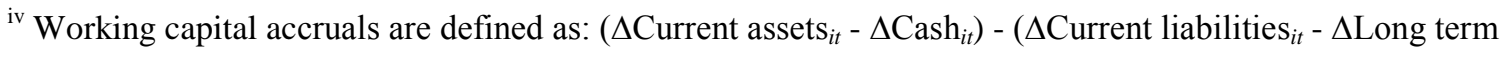
debt in current liabilities ${ }_{i t}-\Delta$ Income taxes payable $_{i t}$ ), where $\Delta$ variable $_{i t}$ denotes the change in that variable from year $t-1$ to $t$ for firm $i$.

${ }^{\mathrm{v}}$ While annual reports of Nordic firms frequently include information regarding the presence of an audit committee, they rarely disclose the identity of the directors that sit on the audit committee. Hence, data availability precluded us from testing the effects of the presence of foreign directors on the firm's audit committee on the level of earnings management.

${ }^{\mathrm{vi}}$ We also estimated the results based on a cross-sectional annual (rather than periodic) estimation of the Modified Jones model. Although this, as expected, reduces our sample sizes, the results remain qualitatively similar to those reported in the paper.

${ }^{\text {vii }}$ A Wald $\chi 2$-test of difference between the two coefficients does not reveal any statistically significant difference in coefficients ( $\chi 2=0.05$; n.s.). 
viii We also performed a change specification analysis in which we tried to tease out the effects of a change in the presence or percentage of non-Nordic foreign directors on the change in earnings management. This, however, did not result in significant effects, which is probably due to the low number of observations involving a change in our test variable. Out of a total of 2,663 firm-year observations, 73 (325) involving a change in D_NONNORDIC (PERC_NONNORDIC).

${ }^{\text {ix }}$ Following the recommendations of Aiken and West (1991), we standardized all continues variables before entering them into the regression analysis. In the regression we include all explanatory variables except $D \_P E R I O D$, which is highly correlated with $L O C A L \_G A A P$.

${ }^{\mathrm{x}}$ We also performed a sub-samples analysis in which we compare the 2,602 firms where $D \_N O N N O R D I C$ $=0$ with the 647 firms where $D \_N O N N O R D I C=1$. The results regarding the effects of $L O C A L \_G A A P$ are in line with the results from the analysis based on the inclusion of an interaction variable.

${ }^{x i}$ Brochet et al. (2013: 17) note that "[t]he TOEFL (Test of English as a Foreign Language) is extensively used as an admission requirement for non-native speakers at various (primarily academic) institutions around the world. The test is designed and administered by the Educational Testing Service (ETS), and has been taken by over 27 million individuals since its introduction in 1964.”

xii We also used the average language distance based per board (using TOEFL scores) and did not obtain significant results either.

xiii We also constructed a measure based on the classification by Lewis (2009), a system that groups languages by families (e.g., Sino-Tibetan, Altaic, Indo-European). Following this classification system, each country is given a score based on the distance between its dominant language and English, with a score of 5 indicating that the language is from a different family and 1 indicating that it is the same language. Brochet et al. (2013: 16) indicate that "[t]he main advantage of this variable is that it accounts for fundamental differences between languages as a continuous variable, recognizing that it is likely easier for a non-native English speaker to learn English if her native language is in the same branch (e.g., German or Dutch) than if it is in a different family (e.g., Turkish or Mandarin).” The use of this alternative measure (again using either the maximum distance based one individual board member or an average distance based on all board members), did not yield significant results either. 